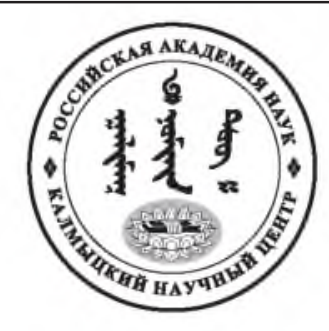

Published in the Russian Federation

Oriental Studies (Previous Name: Bulletin of the Kalmyk Institute

for Humanities of the Russian Academy of Sciences)

Has been issued as a journal since 2008

ISSN: 2619-0990; E-ISSN: 2619-1008

Vol. 14, Is. 2, pp. 364-374, 2021

Journal homepage: https://kigiran.elpub.ru

УДК / UDC 81-114.2

DOI: $10.22162 / 2619-0990-2021-54-2-364-374$

\title{
Способы репрезентации семантики запрета в тувинском языке
}

\section{Байлак Чаи-ооловна Ооржак'}

${ }^{1}$ Тувинский государственный университет (д. 36, ул. Ленина, 667000 Кызыл, Российская Федерация)

доктор филологических наук, ведущий научный сотрудник

D) 0000-0001-8373-9107. E-mail: oorzhak.baylak@imail.ru

(C) КалмНЦ РАН, 2021

(C) Ооржак Б. Ч., 2021

Аннотация. Целью статьи является описание грамматических и лексических средств-выражения семантики запрета в современном тувинском языке, анализ их значений, прагматических и стилистических функций. Материаль и методы. В исследовании используются описательный метод и функционально-семантический и коммуникативно-прагматический подходы. Материалом для исследования послужили примеры из Электронного корпуса текстов тувинского языка. Резульmambl. Определены семантические различия показателей запрета и их функционально-стилистические особенности. Выделены типы запрета (прохибитива), получившие грамматическое и лексическое выражение в тувинском языке, - регулятив, превентив, констатив, корректив. Семантически сравнительно более широким спектром значений запрета обладает аналитическая форма $T$-n болбас - специальный грамматический показатель запрета, выражающий регулятив, превентив, констатив. Bыводы. Проведенное исследование на материале тувинского языка подтверждает данные типологически разных языков о том. что стилистически универсальной передачей значения запрета являются показатели отрицательного императива. Другие же средства выражения запрета, кроме отрицательной формы будущего времени -бас, являются стилистически маркированными. При выражении запрета важное место занимает интонация. которая взаимодействует с собственно формальными его показателями. контекстом и коммуникативной ситуацией. Для других грамматических средств в этой системе показателей индикатива передача значения запрета является не основной их функцией. Это касается отрицательной формы будущего времени на -бас (регулятив, превентив) и формы прошедшего времени на -ды. Последняя передает значение адмонитива. В системе лексико-грамматических средств выражения запрета выделяются лексемы хоржок (превентив), болзун, адыр (корректив), которые не имеют с современном языке определенного частеречного статуса. Лексема запрета болзун представляет собой грамматикализацию глагола бол- в значении «кончать» в форме 3-го лица императива. Обнаруживаются два глагола бол- и 
сокса-, имплицитно выражающие запрет-корректив. Рассмотренные лексико-грамматические и лексические средства запрета относятся к разговорному стилю. В официально-деловом стиле употребляется ряд специальных лексем со значением регулятива, образованный от основы хору-. В это словообразовательное гнездо входят глаголы, прилагательные, наречия. Результаты исследования функционально-семантического поля запрета в тувинском языке будут востребованы в дальнейших исследованиях по модальности в тюркских и других языках.

Ключевые слова: тувинский язык, семантика запрета, прохибитив, отрицательный императив, регулятив, превентив, констатив, корректив

Для цитирования: Ооржак Б. Ч. Способы репрезентации семантики запрета в тувинском языке // Oriental Studies. 2021. T. 14. № 2. C. 364-374. DOI: 10.22162/2619-0990-2021-54-2-364374

\title{
Semantics of Prohibition in the Tuvan Language: Representation Means Revisited
}

\author{
Baylak Ch. Oorzhak ${ }^{1}$ \\ ${ }^{1}$ Tuvan State University (36, Lenin St., 667000 Kyzyl, Russian Federation) \\ Dr. Sc. (Philology). Leading Research Associate \\ 0000-0001-8373-9107. E-mail: oorzhak.baylak@mail.ru \\ (C) KalmSC RAS, 2021 \\ (C) Oorzhak B. Ch., 2021
}

\begin{abstract}
Introduction. The article discusses the linguistic manifestation of prohibition semantics in Tuvan, analyzes the grammatical and lexical means of its expression, determines the semantic differences of the prohibition indicators and their functional/stylistic features. Goals. The paper aims to describe the grammatical and lexical means of expressing the semantics of prohibition in modern Tuvan, to analyze their meanings, pragmatic and stylistic functions. Materials and Methods. The study employs the descriptive method, functional/semantic and communicative/pragmatic approaches. The research material was provided by examples from digital sources of Tuvan-language texts available at: http://www.tuvancorpus.ru/. Results. The research of Tuvan language materials confirms the data from typologically different languages that indicators of the negative imperative are stylistically universal transmitters of the prohibitive meaning. Other means of expressing prohibition - besides the negative form of the future tense $-6 a c$ - are stylistically marked. When it comes to express a prohibition, intonation holds an important place since it interacts with the former's formal indicators proper, context and communicative situation. The paper identifies several types of prohibition (the prohibitive) that have received grammatical and lexical expressions in the Tuvan language - the regulative, preventive, constative, and corrective. Semantically, a comparatively wider range of prohibition values is possessed by the analytical form $T v-n$ болбас - a special grammatical indicator of prohibition expressing the regulative, preventive, and constative. For other grammatical means within this system of indicative indicators, transfer of prohibition values is not a key function of theirs. This is the case of the future negative $-\sigma a c$ (regulative, preventive) and the past $-\partial b l$. The latter conveys a value of the admonitive. The system of lexical and grammatical means of expressing prohibition is distinguished by the lexemes хоржок (preventive), болзун, адыр (corrective) that have no certain part of speech status within the modern language. The prohibition lexeme болзун is a grammaticalization of the verb бол- in the meaning 'to finish' for the third imperative. There are two verbs бол- and сокса- that implicitly express prohibition/correction. The considered lexicogrammatical and lexical means of prohibition belong to the colloquial style. The formal style employs a number of special lexemes with the meaning of the regulative formed from the stem xopy-. This word-formation nest includes verbs, adjectives, adverbs. The results of the study in the functional/ semantic field of prohibition in the Tuvan language shall be demanded in further research on modality in the Turkic and other languages.
\end{abstract}


Keywords: Tuvan, prohibition semantics, prohibitive, negative imperative, regulative, preventive, constative, corrective

For citation: Oorzhak B. Ch. Semantics of Prohibition in the Tuvan Language: Representation Means Revisited. Oriental Studies. 2021. Vol. 14 (2): 364-374. (In Russ.). DOI: 10.22162/26190990-2021-54-2-364-374

\section{है}

\section{Введение}

В развитии общества запреты находили отражение в тех или иных социальных нормах поведения и являлись коммуникативным средством контроля поведения членов коллектива. Знание индивидом этих запретов и умение действовать в рамках этих ограничений, адекватно реагировать на них в определенных ситуациях - залог успешного коммуникативного взаимодействия в обществе.

Семантика запрета (прохибитива) является одной из языковых универсалий, которая обнаруживается практически во всех известных языках. Исследование прохибитива тесно связано с анализом императива и изучением отрицания.

Запрет рассматривается как особый тип побуждения, который обладает собственными семантическими, функциональными, прагматическими свойствами и набором языковых средств выражения [Храковский, Володин 1986; Сарайкина 2007].

Типовым значением запрета является побуждение адресата к неосуществлению, прекрашению совершаемого им действия. «...использование императива в отрицательных предложениях не подразумевает простое отрицание побуждения; здесь возникают особые значения, а именно требование прекратить осуществляющееся в момент речи действие, а также не совершать определенных действий в будущем» [Молчанова 1976: 17]. Коммуникативная ситуация запрешения характеризуется как асимметричная, при которой намерения говорящего и действия адресата(ов) не совпадают.

Семантика запрета и средств ее репрезентации в языках мира рассматривались во многих работах [Беляева 1992; Шмелева 1990; Шатуновский 2000; Иосифова 2010; Фатеме 2011; и др.]. Специальному исследованию семантики запрета и средств ее репрезентации в русском языке посвящено исследование О. В. Сарайкиной. Автор описывает свойства многообразных языковых средств с семантикой запрета, функционирующих на разных уровнях языковой системы, с точки зрения функционально-семантического и коммуникативно-прагматического подходов [Сарайкина 2007].

Выделению формальных типов прохибитива, их описанию посвящены работы [Храковский, Володин 1986; Бирюлин. Храковский 1992; Кибрик 2001; van der Auwera, Lejeune, Goussev 2005]. На материале различных европейских языков современные исследователи выводят различные типы запрета (прохибитива): запрет-регулятив, запрет-превентив, запрет-констатив и запрет-корректив, при этом под «запрещение определяется как речевое действие, направленное на побуждение адресата к неосуществлению, прекращению или видоизменению действия, названного говорящим [Сарайкина 2007: 8].

Регулятив направлен на регулирование и координирование неречевого поведения субъекта в условиях конвенционального об̆щения. Превентивы направлены на предотвращение еще не совершившегося речевого или неречевого действия адресата в межличностном и групповом общении. Констативы употребляются в функции, направленной на информирование адресата о неизвестном ему запрещенном факте или на констатацию определенного запрешенного факта. Коррективы направлены на изменение совершающегося в момент речи речевого или неречевого действия адресата в условиях межличностного и группового общения [Сарайкина 2007: 9].

К прохибитиву семантически близко стоят адмонитивы, передающие опасения говорящего, предупреждения о возможном наступлении неблагоприятной, опасной ситуации или о нежелательном стечении обстоятельств, действий. В лингвистике имеет- 
ся мнение, что адмонитив является особым типом прохибитива [Плунгян 2011: 439]

Определению национальной специфики концепта запрет и особенностям его репрезентации в тувинских героических сказаниях посвящена статья Л. К. Хертек [Хертек 2020]. Автор исследует смысловой потенциал концепта запрет в эпическом дискурсе с привлечением этнографического и культурологического материала; определяет роль концепта запреm в эпическом миромоделировании.

С точки зрения языковой репрезентации запрета данное фукционально-семантическое поле на материале тувинского языка еще не было объектом специального изучения. Целью данной статьи является анализ функционально-семантического поля запрета и средств ее выражения в тувинском языке

\section{Материалы и методы}

Материалом для исследования послужили примеры из электронных источников текстов на тувинском языке [ЭКТТЯ] ${ }^{1}$. В исследовании используются описательный метод и функционально-семантический и коммуникативно-прагматический подходы.

\section{Языковая репрезентация семантики запрета в тувинском языке}

Фукционально-семантическое поле запрета в тувинском языке представлено четко ограниченным количеством языковых средств разного уровня. На уровне грамматики семантика запрета выражается отрицательными формами императива и настоящего / будущего времени, а также специальными аналитическими показателями, в структуру которых входят предикаты со значением запрета. На уровне лексики исследуемое значение передается специальными лексемами, выражающими данную категорию. На наш взгляд, центром функционально-семантического поля запрета является форма отрицательного императива. Ближе к центру функционально-семантического поля запрета расположены: специальная аналитическая форма $T v-n$ болбас ${ }^{2}$ и отрицательная форма будущего

\footnotetext{
${ }^{1}$ Примеры без указания на источник принадлежат автору.

${ }^{2}$ Аналитическая форма, состоящая из формы деепричастия на - $n$ (Tv-n) и вспомогательного глагола бол- 'быть' в форме отриңания на -бас.
}

времени (-бас). Здесь заканчивается собственно грамматическое выражение значения запрета. Кроме того, в это поле входят и лексические средства выражения категории запрета: лексемы хоржск 'нельзя' и болзун 'хватит', aдыр 'погоди', глаголы бол- 'быть' и сокса- 'прекращать', а также целое словообразовательное гнездо с семантикой запрета, восходящее к основе хорy-. К этой основе восходит и лексема хоржок 'нельзя'. Рассмотрим каждое из языковых средств и семантические типы запрета, выражающиеся ими.

\section{1. Отрицательный императив как ос-} новное средство выражения семантики запрета и центр функционально-семантического поля запрета

Формы 2 и 3-го лица отрицательного императива являются, скорее всего, центром функционально-семантического поля запрета. Если формы императива положительной полярности выражают различные значения побуждения к совершению действия (приказ, просьба, призыв, совет и т. д.), то отрицательный императив передает побуждение к его не-совершению запрет, причем отрицательный императив может выражать как превентив, так и корректив:

(1) Чугаала! 'Говори!' — Чугаалава! 'Не говори!', 'Замолчи!'3.

(2) Чугаалацар! 'Говорите!' - Чугаалавацар! 'Не говорите!', 'Замолчите!';

(3) Чугаалазын! 'Пусть говорит!' - Чугаалавазын! 'Пусть не говорит!', 'Пусть замолчит!';

(4) Чугаалазыннар! 'Пусть говорят!' - Чугаалавазыннар! 'Пусть не говорят!', 'Пусть замолчат!'

Особой функцией отрицательной формы императива 3-го лица является то, что он регулярно может передавать значение адмонитива:

(5) Көрдүнер бе? Бо ьияи кырынуарже барып yипазын! 'Видели? (Смотрите) как бы это дерево на вас не упало!' [ЭКТТЯ. Э. Донгак. Сыын чады. 1986];

(6) Дугар дыцинап каатпазын! '(Смотри), как бы Дугар не услышал!' [ЭКТТЯ. М. Эргеп. Таңды-Ууланың кижилери. 1991].

${ }^{3}$ Здесь и далее перевод примеров выполнен автором. 
Выражение запрета отрицательными формами императива в тувинском языке присуще неофициальной речи, в том числе разговорной. В употреблении 2-го лица отрицательного императива статус участников речевой ситуации характеризуется как неравный: говорящий обладает правом запрещать в силу своего возраста или социального статуса. Употребление 3-го лица отрицательного императива в значении предупреждения характерно для ситуаций, когда говорящий обладает «ситуативным правом» запрещать в силу обладания им бо́льшей информацией о возможном неблагоприятном результате для адресата.

Значение опасения и предупреждения регулярно передается также формой прошедшего времени на - $\partial ы /-\partial u /-\partial y /-\partial Y$; $-m$ bl /-mu/-my/-mY во 2 и 1-м лице:

(7) Оваарымчалыг болунар, кээn дүитүнер! 'Будьте осторожны, смотрите не упадите!';

(8) Салып үндүрдум-(не)! 'Запускаю (петарды, будьте осторожны)!'

Семантическое соотношение отрицательного императива и формы прошедшего времени со значением адмонитива следующее:

- формой на -ды говорящим выражается предупреждение адресату-суб́ъекту, способному контролировать и регулировать свои действия во избежание опасного или неблагоприятного исхода своих же действий:

- при форме на -базын(нар) выражается предупреждение адресату-агенсу о возможном неблагоприятном воздействии на него со стороны эффектора

Эффектор не является «разумным существом и, следовательно, не может контролировать ситуацию, но может рассматриваться как активный источник энергии, вызывающий изменения» [Плунгян 2011: 162]. Эффектором может быть, например, природная стихия или природный объект, животное, а также человек (см. пример 6), который не может ситуативно контролировать действие, названное глаголом.

\section{2. Аналитическая форма Tv-n болбас как специальное средство выражения за- прета}

Запрет выражается в оппозиции с разрешением отрицательной аналитической формой $\mathrm{Tv}$ - $n$ болбас, которая передает «значения запрета или предупреждения о невозможности совершить действие) [Ондар 1996: 127]. Аналитическая форма Tv-n болбас в 3-м лице выражает:

1) значение запрета-регулятива для обобщенного лица как ограничения потенциальных возможностей разворачивания действий и событий, обусловленного официально принятыми нормами:

(9) Кирип болбас! 'Не заходить!';

(10) Таакпылап болбас! 'Не курить!';

2) значение запрета-превентива, основанного на личных знаниях и жизненном опыте, соотнесенного с реальным положением дел в конкретной ситуации, как принятое субъектом сознательное ограничение возможностей совершения действий в целях предотвращения нежелательного воздействия со стороны внешних сил:

(11) НИимээргеп болбас. (Хаяларга бичии-ле дааш чаңгылангаш, кайы оранчокка дыңналы бээр) БІлацгья дүне удуп болбас... 'Нельзя шуметь. (Даже маленький шум в скалах слышится эхом) Особенно нельзя спать ночью...' [ЭКТТЯ. И. Бадра. Арзылаң Күдерек. 1996];

(12) ...орукче үнер, бо кара эзииден чоннун чоон оруунче союп үнер, чуале харык-иинекти чидирип болбас '... (нужно) выходить на дорогу, из этого дремучего леса выходить ползком на большую дорогу, только нельзя терять силы' [ЭКТТЯ. А. Даржай. Чурттаарын күзезиңзе. 1984];

3) значение информативного запрета-констатива как категорической рекомендации либо предупреждения и наказа не совершать то или иное действие, продиктованное знаниями фактов и жизненным опытом говорящего:

(13) Эрги алдар-биле чурттап болбас, ол хеп ьиккаи, элеп каар чоор 'Нельзя жить былой славой: она, как одежда, обветшает' [ЭКТТЯ. А. Даржай. Чурттаарын күзезиңзе. 1984];

(14) Амыдырал чеже-даа бергедеп келзе коргуn-суртеп, девидеп болбас, уруум 'Если даже жизнь станет сложной, нельзя бояться, метаться в волнении, дочка' [ЭКТТЯ. Э. Донгак. Кежик кыс. 2010].

Аналитическая форма $T v-n$ болбас употребляется в разговорной речи в наставлениях, назиданиях, поучениях. Кроме того, она широко употреб́ляется в официаль- 
но-деловой речи (в предписаниях и правилах, обращенных к обобщенному лицу), а также когда адресат высказывания выявляется из контекста.

3. Отрицательная форма будущего времени на -бас в функции репрезентанта превентивного запрета

Одной из функций отрицательной формы будущего времени на -бас является выражение превентивного запрета прямому адресату во 2-м лице (примеры 15,16$)$ и регулятивного запрета обобщенному субъекту в 3-м лице (примеры 17, 18):

(15) Мени сураглавас силер. Мени кээп чораaн деn, кымга-даa blbimmaвас сен 'Обо мне не расспрашивайте. О том, что я приходил, никому не говори' [ЭКТТЯ. Ш. Суван Хемчик нояны. 2009];

(16) Бо холудну моон уитуп, иимчетпес сен 'Не вытаскивай эту руку отсюда, не шевели ею' [ЭКТТЯ. В. Көк-оол. Шиилер. 1976]; ну!';

(17) Чурум үревес! 'Не нарушать дисципли-

(18) Мегелевес! 'Нельзя врать!'

Запрет-регулятив в 3-м лице употребляется при обобщенном субъекте для передачи общих правил запрета согласно тем или иным принятым нормам общества, морали, этических принципов, обладает высокой степенью категоричности и - часто - эмоциональности.

4. Лексемы хоржск, болзун, адыр как специальные лексико-грамматические средства выражения прохибитива

Особым лексико-грамматическим выразителем семантики запрета служит лексема хоржок 'нельзя', выражающая запрещение, недозволение, отсутствие разрешения на намерение или вопрос говорящего. Рассмотрим примеры:

(19) Балды-биле одура иааптар, честей Хоржск! 'Отрубить (корни дерева) топором, дядя - Нельзя!' [ЭКТТЯ. М. Кенин-Лопсан. Чүгүрүк Сарала. 1965]:

(20) Мен база чонар мен бе, ачай? Хоржск, оглум. Көөрге ылныл. Чудук чонары берге '- Я тоже буду тесать, отец? - Нельзя, сынок. Когда смотришь, кажется простым делом. Тесать бревно трудно' [ЭКТТЯ. Э. Донгак. Эрги хонаштар. 1983]

К лексическим средствам выражения запрета действия относятся также сло- ва болзун 'хватит, довольно, достаточно, полно' (пример 21) и адыр 'погоди' (пример 22), используемые в диалогах и служащие запретом-коррективом, прерывающим действие, которое может иметь с точки зрения говорящего нежелательные последствия для участников речевой ситуации. Например, междометие:

(21) Че, ам болзун, Найдан. Эмин эрте бээривиске кайьи боор 'Ладно, сейчас хватит, Найдан. Слишком переходить границы не надо' [ЭКТТЯ. М. Дуюнгар. Хөлегелер. 1996];

(22) Aдыр, авттыг кижи чоктап ор, кылм боор, көрем 'Погоди, едет всадник, кто же это может быть, посмотри' [ЭКТТЯ. К. Черлиг-оол. Аялга. 1990].

Форма болзун восходит к форме повелительного наклонения от глагольной основы бол- 'быть' в одном из своих значений, а именно в значении 'кончать, заканчивать, доходить до предела' [ЭСТЯ 1978: 187].

Что касается лексемы хоржок, то она, видимо, образована от основы хора'вред' (см. в [ЭСТЯ 2000: 72]) и лексемы чок 'нет'. Последняя участвует как словообразовательный формант в ряде лексем со значением отсутствия (см. об этом, например, в [Дамбаа 2005: 15]). И если лексемой хоржок выражают недопущение того или иного действия в силу принятых в том или ином обществе норм, то последние болзун, adыр передают прерывание процесса и запрет (неразрешение) на продолжение осуществления действия.

Частеречный статус слов болзун и хоржск не определен. Лексема адыр некоторыми исследователями относится к междометиям [Сат, Салзынмаа 1980: 241].

По своей семантике все три рассматриваемые лексемы, по-нашему мнению, могут быть отнесены либо к категории состояния либо к модальным частицам. Данный вопрос пока остается открытым и требует дальнейшего решения

\section{5. Лексемы с семантикой запрета, вос-} ходящие к основе $x о р y$ -

Наряду с этим функционирует словообразовательное гнездо с семантикой запрета, восходящее к основе хору-: глаголы хоpyyp 'запрещать', хоругдаap 'заключать под стражу'; существительные хоруг 'запрет, запрешение', хоругдал '1. Запрет, запреше- 
ние; 2. Заключение под стражу'; наречие хоруглуг 'запрещено, воспрещено' (см. таюже в [TPC 1968: 485].

Данный ряд лексем, определяемый как репрезентанты запрета-регулятива. употребляются в книжном стиле и официально-деловом дискурсе. Употребение их в разговорном дискурсе предполагает различные обсуждения в бытовом общении, например. о том или ином запрете, исходящем от органов власти, официальных или других авторитетных лиц

В Этимологическом словаре тюркских языков указывается, что основа қо.ракору- / коры- / хору- выражает в тюркских языках значения: 1. огораживать, обносить загородкой / забором; 2. запрещать, налагать запрет; хранить, охранять; сохранять; беречь, оберегать, стеречь, защищать, оборонять; 3. покровительствовать, поддерживать; 4. задержать, удержать; 5. покрывать расходы [ЭСТЯ 2000: 75]

В тувинском языке в основе хору-реализуется из указанных второе значение «запрешать». Глагол хоруур 'запретить, запрещать' передает значение “не позволить кому-либо, делать что-либо, какое-либо действие», управляет дательным и винительным падежами.

(23) Оолдар ыллым-чылыци олурганнар, чүге дээрге Саадак дицмирээикии үезинде алгырарын болгаи маниажырын шытегыты хоруп каан 'Мальчишки очень тихо сидели, потому что Саадак строго запретил во время грома кричать и бегать' [ЭКТТЯ. М. Кенин-Лопсан. Чүгүрүк Сарала. 1965];

(24) Адыг өлурерин хораан турда-ла, ийи-чацгыс тотчеглекчилер тайбыи чораан амытаннарже мези арны бээр чүве-дир ийин 'Heсмотря на то, что запрещено убивать медведя. редкие браконьеры покушаются на мирно живущих зверей' [ЭКТТЯ. Э. Донгак. Чолдак аңчының чугаалары. 1982];

(25) Бнчангаи мацаа чопиэээрел чок ацнаарын хоруп каан 'Поэтому здесь запретили охотиться без разрешения' [ЭКТТЯ. Э. Донгак. Чолдак аңчының чугаалары. 1982].

Основа хору- в тувинском языке дала развитию целого ряда других лексем. Рассмотрим словообразовательное гнездо, образованное на базе исходной основы хору-. Глагол хоругдаар 'заключать под стражу' образован в результате присоединения к глагольной основе хору- словообразовательного форманта -г (хору-г 'запрет, запрещение') и продуктивного словообразова- тельного аффикса-ла/-да-/-ma. Далее от нее образуется основы понудительного залога хоругдаm- 'дать заключить под стражу', хоpугдатmыр 'заставить заключить под стражу', которые в свою очередь послужили основой для образования причастия хоругдаттырган 'заключенный под стражу':

(26) Колхозтун хоралакчыларын шолүурун шөлуп, тудуп хоругдаарын хоругдаан 'Из колхозньх вредителей тех, кого нужно сослать, сослали, кого нужно заключить под стражу заключили под стражу' [ЭКТТЯ. Э. Донгак. Эрги хонаштар. 1983].

К производной глагольной основе $х о$ ругда- восходит и существительное хоругдал '1. Запрет, запрещение; 2. Заключение под стражу', образованное при помощи аффикса $-\pi$

(27) Даргавыс медеге аъттар оъткарарын чопиээревес киюси болгай, аъттарымны эки тоткулап алзын дээи, ол хоругдалды урепкеним ол 'Наш председатель не разрешает пасти лошадей на клевере, (но) чтобы мои лошади досыта напаслись, я нарушил этот запрет' [ЭКТТЯ. С. Сарыг-оол. Хүннүң ыраажылары. 1977].

Реализация второго значения лексемы хоругдал видна в следующих примерах:

(28) Та хоругдалдан дескен дургун чуве, та орус хаанның каржы иииткелинден дезип келчик бе, Хемчик ондарларынылу аразынга Мыльтлай деп аттыг орус кижи чурттай берген 'Неизвестно, беглең ли он из тюрьмы или, может быть, сбежал от жестокого суда русского ңаря, среди рода ондар, проживавших в долине реки Хемчик, поселился русский человек по имени Николай' [ЭКТТЯ. Е. Танова. Ширбиилиң холдан салба. 1993];

(29) Олар-биле демиселим мээн бодумну хоругдал адаанче киириптерин ьтчан кайьн каразыыр ий кк мен 'Как я мог тогда подумать, что борьба с ними приведет меня к заключению под стражу'. Последний пример демонстрирует устойчивое сочетание хоругдал адаанче кир‘попадать под заключение под стражу' [ЭКТТЯ. М. Дуюнгар Бөрү дүнү. 1991].

Значение лексемы хоругдал «заключение под стражу» дало развитие понятию хоругдал бажыңы 'тюрьма; помещение, в котором содержатся заключенные' (букв. дом заключения):

(30) Дужуууста чунар-бажыңче шагдаалар хөй-ле кижини киир суруп турлар. Оларны хоругдал бажсыңының улузу дээр чораан 'В баню на- 
против нас милиционеры заводят многочисленных людей. Говорят, это люди из тюрьмы' [ЭКТТЯ. Е. Танова. Ширбиилиц холдан салба. 1993].

От существительного хоруг 'запрет, запрещение' образовано наречие хоруглуг 'запрещено, воспрещено':

(31) Kайь-хамаан чок куда-хувуй кылырыры, эн ьиланугыя сиген-тараа уезинде хоруалуг чүве болгай 'Устраивать беспорядочно свадьбы, особенно во время покоса, запрешено' [ЭКТТЯ. М. Кенин-Лопсан. Чүгурүк Сарала. 1965];

(32) ППак ол күстен бээр Пөитуг-Эзим иитин аңнаары хоруглуг 'Начиная с той осени в местечке Поштуг-Эзим охота запрещена' [ЭКТТЯ. Э. Донгак. Чолдак аңчыныц чугаалары. 1982]

\section{6. Глаголы бол- и сокса-, имплицитно} выражающие корректив

Два глагола бол- и сокса-, инклюзивно выражающие семантику «прекращать», функционируют в тувинском языке как речевые маркеры. В императиве 2-го лица они оба передают приказ о прекращении совершения того или иного действия. Рассмотрим примеры:

(33) - Болунзар, шагдаалар кел чыдыр! 'Прекращайте, милиционеры идут!' [ЭКТТЯ. В. Хомушку. Мончарлыг кижи. 1986];

(34) - Сокса, Марта, сокса! ЧҮY болган чүвел? 'Прекрати, Марта, прекрати! А что вообще случилось?' [ЭКТТЯ. С. Сюрюн-оол. АкТөш. 1984].

В 3-м лице глагол сокса- (соксазын) выражает опосредованный приказ, тогда как форма 3-го лица глагола бол- (болзун) находится, видимо, на стадии грамматикализации и ее перехода в разряд модальных частиц (см. выше пример 4)
(35) Сокса! Болзун! ШІалырава, магым чиве! 'Прекращай! Хватит! Не болтай, не трать мое время!' [ЭКТТЯ. С. Сарыг-оол. Хүннүң ыраажылары. 1977];

(36) - Че, ам болзун, оолдар. Четкини чежип, бальктарны сальптыңар 'Ладно, достаточно, парни. Развяжите сеть, отпустите рыб' [ЭКТТЯ. Е. Танова. Ширбиилиц холдан салба. 1993].

Глагол бол- является одним из основных тюркских полисемантичных глаголов. Одним из его значений выступает семантика «заканчивать, прекращать», которая не была учтена при составлении тувинских языковых словарей. В этом значении он часто функционирует в разговорной речи.

\section{Выводы}

Проанализированные грамматические и лексические средства выражения семантики запрета в современном тувинском языке различаются по своим значениям и прагматическим, стилистическим функциям. Отрицательный императив является типичным и универсальным репрезентантом значения запрета и в тувинском языке, как и в других языках. Другие средства выражения запрета, кроме отрицательной формы будущего времени -бас, являются стилистически маркированными (см. таблицу 1).

При выражении запрета важное место занимает интонация, которая взаимодействует с собственно формальными его показателями, контекстом и коммуникативной ситуацией. Реализация функциональных типов запрета грамматическими и лексическими средствами выражения функционально-семантическом поле представлена в таб̆лице 1.

Таблица 1. Семантика и стилистическая дифференциация средств выражения семантики запрета

[Table 1. Semantics and stylistic differentiation of means employed to express the semantics of prohibition]

\begin{tabular}{|c|c|c|c|c|c|c|c|}
\hline \multirow{2}{*}{\multicolumn{2}{|c|}{$\begin{array}{l}\text { Средства выражения семантики } \\
\text { запрета }\end{array}$}} & \multicolumn{4}{|c|}{$\begin{array}{c}\text { Функциональные типы } \\
\text { запрета } \\
\end{array}$} & \multirow{2}{*}{ 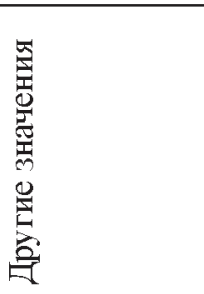 } & \multirow{2}{*}{ 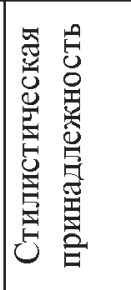 } \\
\hline & & 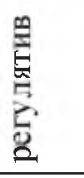 & $\begin{array}{l}\text { 四 } \\
\text { 恶 } \\
\text { 兽 } \\
\end{array}$ & 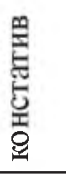 & 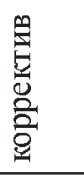 & & \\
\hline \multirow[t]{2}{*}{ Отрицательный императив } & 2-е лицо & - & + & - & + & - & \multirow[t]{2}{*}{$\varnothing$} \\
\hline & 3-е лицо & - & + & - & + & адмонитив & \\
\hline
\end{tabular}


Oriental Studies. 2021. Vol. 14. Is. 2

\begin{tabular}{|c|c|c|c|c|c|c|c|}
\hline \multirow{2}{*}{$\begin{array}{l}\text { Форма прошедшего } \\
\text { времени на - } \partial b l\end{array}$} & 2-е лицо & - & - & - & - & адмонитив & \multirow[t]{2}{*}{$\mathrm{P}$} \\
\hline & 1-е лицо & - & - & - & - & адмонитив & \\
\hline \multirow{2}{*}{$\begin{array}{l}\text { Отрицательная } \quad \text { форма } \\
\text { будущего времени -бас }\end{array}$} & 2-е лицо & - & + & - & - & - & \multirow[t]{2}{*}{$\varnothing$} \\
\hline & 3-е лицо & + & - & - & - & - & \\
\hline $\begin{array}{l}\text { Аналитическая форма } \\
\text { Tv-n болбас }\end{array}$ & 3-е лицо & + & + & + & - & - & $\bar{K}$ \\
\hline Частица хоржок & & - & + & - & - & - & $\mathrm{P}$ \\
\hline Частица aдыıp & & - & - & - & + & - & $\mathrm{P}$ \\
\hline Частица болзун & & - & - & - & + & - & $\mathrm{P}$ \\
\hline $\begin{array}{l}\text { Лексемы, восходящие к } \\
\text { основе хору- }\end{array}$ & & + & - & - & - & - & $\mathrm{K}$ \\
\hline \multirow[t]{2}{*}{ Глагол сокса- } & 2-е лицо & - & - & - & + & - & $\mathrm{P}$ \\
\hline & 3-е лицо & - & - & - & + & - & $\mathrm{P}$ \\
\hline Глагол бол- & 2-е лицо & - & - & - & + & - & $\mathrm{P}$ \\
\hline
\end{tabular}

Принятые обозначения: "+" - наличие признака; "- - - отсутствие признака; "Ø" - стилевая немарткированность признака; "Р" - принадлежность разговорному стилю; “К” — принадлежность книжному стилю

Устанавливается, что функциональные типы запрета, выделенные для других языков, в тувинском языке проявляются следующим образом: значение запрета-превентива получает большую маркированность как грамматически, так и лексически; примечательно, что регулятив выражается посредством отрицательной формы будущего времени на -бас, она также входит с структуру аналитической формы с тем же значением; значение корректива передается отрицательным императивом и лексическими средствами; значительно реже представлено значение констатива — как одно из значений аналитической формы $T v-n$ болбас. Последняя обладает сравнительно более широким значением, так как может передавать три значения: регулятив, превентив, констатив.

Отрицательный императив 3-го лица может передавать и адмонитивное значение. Адмонитив в тувинском языке может также передаваться формой прошедшего времени на -дbl. Проанализированный материал показал, что более грамматикализованным в тувинском языке является значение превентива, менее всего - констатива.

\section{Источники}

ЭКТТЯ - Электронный корпус текстов тувинского языка [электронный ресурс] // URL: http://www.tuvancorpus.ru/ (дата обращения: 10.12.2020).
На уровне лексики семантика запрета-регулятива содержится в целом ряде лексем, восходящих к древней основе хору. Приводятся также два глагола, инклюзивно содержащие сему запрета-регулятива (сокса- и бол-), которая особенно четко проявляется в императиве. Последний из них представляет собой один из основных тюркских полисемантичных «бытийных» глаголов, одним из значений которого выступает семантика «прекращать». Отмечается функционирование специальных прохибитивных показателей - лексем хоржск, болзун и адыр, частеречный статус которых еще не определен.

Дальнейшее развитие в исследовании данной темы представляется в определении семантического сочетания определенных лексико-семантических групп глаголов с лексико-грамматическими показателями прохибитива в тувинском языке. Отдельным вопросом рассмотрения будет семантическое соотношение положительных и отрицательных форм соответствующих форм в глагольной парадигме.

\section{Sources}

Online Tuvan Text Corpus. Available at: http:// www.tuvancorpus.ru/ (accessed: December 10, 2020). (In Tuv.) 
Литература
Беляева 1992 - Беляева Е. И. Грамматика и прагматика побуждения: английский язык. Воронеж: Изд-во ВГУ, 1992. 168 с.

Бирюлин, Храковский 1992 - Бирюлин Л. A., Храковский В. С. Повелительные предложения: проблема теории // Типология императивных конструкций. М.: Наука, 1992. C. 5-50.

Дамбаа 2005 - Дамбаа О. В. Лексические средства отрицания в тувинском языке в сопоставлении с южносибирскими тюркскими, монгольским и древнетюркским языками: автореф. дисс. ... канд. филол. наук. Новосибирск, 2005. $20 \mathrm{c}$.

Иосифова 2010 - Иосифова В. Е. Побудительные высказывания, выражающие запрещение // Преподаватель. ХXI век. 2010. № 3. C. $278-283$.

Кибрик $2001-$ - Кибрик A. E. (ред.). Багвалинский язык: грамматика, тексты, словари. М. Наследие, 2001. 930 с.

Молчанова 1976 - Молчанова Г. П. Императивные предложения и их лексико-грамматическая характеристика в современном английском языке // Сб. науч. тр. Моск. пед. ин-та иностранных языков. Вып. 105. Минск: Издво МГПИИЯ. 1976. С. 29-50.

Ондар 1996 - Ондар Ч. С. Семантика аналитических конструкций с вспомогательными глаголами бол-, иьлда-, чада- в тувинском языке // Языки коренных народов Сибири. Вып. 3. Новосибирск: Институт филологии CO PAH, 1996. C. 120-129.

Плунгян 2011 - Плунгян B. A. Введение в грамматическую семантику: грамматические значения и грамматические системы языков мира. М.: Изд-во РГГУ, 2011. 669 с.

Сарайкина 2007 - Сарайкина О. В. Репертуар языковых средств выражения семантики запрета: автореф. дисс. ... канд. филол. наук. M., 2007. $21 \mathrm{c}$.

Сат, Салзынмаa 1980 - Cат LI. Ч., Салзынмaа E. Б. Амгы тыва литературлуг дыл (= Современный тувинский язык). Фоне-

\section{References}

Belyaeva E. I. English Language: Grammar and Pragmatics of the Hortative. Voronezh: Voronezh State University, 1992. 168 p. (In Russ.)

Biryulin L. A., Khrakovsky B. S. Imperative sentences: problems of theory. In: Typology of Imperative Constructs. Moscow: Nauka, 1992. Pp. 5-50. (In Russ.)

Dambaa O. V. Tuvan Lexical Negation Means: A Comparative Perspective from Southern Sibe- тика, морфология. Кызыл: Тув. кн. изд-во, $1980.257 \mathrm{c}$

ТРС 1968 - Тувинско-русский словарь / под ред. Э. Р. Тенишева. М.: Сов. энциклопедия, $1968.648 \mathrm{c}$

Фатеме 2011 - Фатеме Назари. Способы выражения запрета в русском языке // Вестник Нижегородского университета им. Н. И. Лобачевского. 2011. № 6(2). С. 684-686.

Хертек $2020-$ Хертек Л. К. Лингвокультурный концепт ЗАПРЕТ в тувинских героических сказаниях // Филологические науки. Вопросы теории и практики. Тамбов: Грамота, 2020. Т. 13. Вып. 7. С. 170-174.

Храковский, Володин 1986 - Храковский В. С. Володин А. П. Семантика и типология императива. Русский императив. Л.: Наука, 1986. $272 \mathrm{c}$.

Шатуновский 2000 - Шатуновский И. Б. Речевые акты разрешения и запрещения в русском языке // Логический анализ языка: Языки этики. М.: Языки русской культуры, 2000. C. 319-325.

Шмелева 1990 - Шмелева E. A. Разрешение и запрещение как побудительные речевые акты // Функционально-типологические аспекты анализа императива: в 2 ч. Ч. 2. Семантика и прагматика повелительных предложений. М.: Институт языкознания $\mathrm{AH}$ CCCP, 1990. C. 66-71.

ЭСТЯ 1978 - Севортян Э. В. Этимологический словарь тюркских языков:Общетюркские и межтюркские основы на букву 'Б'. М.: Наука, $1978.348 \mathrm{c}$.

ЭСТЯ 2000 - Этимологический словарь тюркских языков: Общетюркские и межтюркские основы на букву 'Қ' / авт. сл. статей Л. С. Левитская, А. В. Дыбо, В. И. Рассадин. М.: Наука, 2000. 261 с.

van der Auwera, Lejeune, Goussev 2005 - van der Auwera J., Lejeune L., Goussev V. The Prohibitive // Haspelmath M., Dryer M. S., Gil D., Comrie B. (eds.). The World Atlas of Language Structures. New York: Oxford University Press, 2005. P. 290-293.

rian Turkic, Mongolian, and Old Turkic Languages. Cand. Sc. (philology) thesis abstract. Novosibirsk, 2005. 20 p. (In Russ.)

Iosifova V. E. Hortative sentences of prohibition. Prepodavatel. XXI vek. 2010. No. 3. Pp. 278283. (In Russ.)

Khertek L. K. Linguocultural concept PROHIBITION in the Tuvan heroic tales. Philology. Theory \& Practice. 2020. Vol. 13. No. 7. Pp. 170174. (In Russ.) 
Khrakovsky V. S., Volodin A. P. Semantics and Typology of the Imperative: Russian Imperative. Leningrad: Nauka, 1986. 272 p. (In Russ.)

Kibrik A. E. (ed.) Bagvalal Language: Grammar, Texts, Dictionaries. Moscow: Nasledie, 2001. 930 p. (In Bag. and Russ.)

Levitskaya L. S., Dybo A. V., Rassadin V. I. Etymological Dictionary of Turkic Languages: Common and Intra-Turkic Word Stems Beginning with the Letter ' $\mathrm{K}$ '. Moscow: Nauka, 2000. 261 p. (In Russ. and Turk.)

Molchanova G. P. Imperative sentences and their lexico-grammatical characteristics in modern English. In: Minsk State Pedagogical Institute of Foreign Languages. Collected Papers. Vol. 105. Minsk: Minsk State Pedagogical Institute of Foreign Languages, 1976. Pp. 29-50. (In Russ.)

Nazari F. Linguistic means of expressing prohibition in the Russian language. Vestnik of Lobachevsky University of Nizhni Novgorod. 2011. No. 6 (2). Pp. 684-686. (In Russ.)

Ondar Ch. S. Semantics of Tuvan analytical constructs with the auxiliary verbs бол-, иьлда-, yada-. In: Languages of Indigenous Siberian Peoples. Vol. 3. Novosibirsk: Institute of Philology (Sib. Branch of RAS), 1996. Pp. 120129. (In Russ.)

Plungyan V. A. Introduction to Grammatical Semantics: Grammatical Meanings and Grammatical Systems of Languages. Moscow: Russian State University for the Humanities, 2011. 669 p. (In Russ.)
Saraykina O. V. Semantics of Prohibition: The Scope of Language Means Revisited. Cand. Sc. (philology) thesis abstract. Moscow, 2007. 21 p. (In Russ.)

Sat Sh. Ch., Salzynmaa E. B. Modern Tuvan: Phonetics, Morphology. Kyzyl: Tuvan Book Publ., 1980. 257 p. (In Tuv. and Russ.)

Sevortyan E. V. Etymological Dictionary of Turkic Languages: Common and Intra-Turkic Word Stems Beginning with the Letter ' '. Moscow: Nauka, 1978. 348 p. (In Russ. and Turk.)

Shatunovsky I. B. Speech acts of permission and prohibition in Russian. In: Logical Analysis of Language. Languages of Ethics. Moscow: Yazyki Russkoy Kultury, 2000. Pp. 319-325. (In Russ.)

Shmeleva E. A. Permission and prohibition as hortative speech acts. In: The Imperative. Functional and Typological Aspects of Analysis. In 2 vols. Vol. 2: Semantics and Pragmatics of Imperative Sentences. Moscow: Institute of Linguistics (USSR Academy of Sciences), 1990. Pp. 66-71. (In Russ.)

Tenishev E. R. (ed.) Tuvan-Russian Language. Moscow: Sovetskaya Entsiklopediya, 1968. 648 p. (In Tuv. and Russ.)

van der Auwera J., Lejeune L., Goussev V. The Prohibitive. In: Haspelmath M., Dryer M. S., Gil D., Comrie B. (eds.). The World Atlas of Language Structures. New York: Oxford University Press, 2005. Pp. 290-293. (In Eng.) 